\title{
SANITARY-TOPOGRAPHICAL STUDIES IN ESTONIA DURING THE 1920s AND 30s
}

The purpose of general and individual hygiene is as far as possible to prevent unnecessary illness and death. The practice of preventive medicine presupposes knowledge of the causes of the diseases. On the whole, this means that the goal of hygiene must be to eliminate the exogenous causes of disease. The prevention of endogenous diseases is possible only to a limited extent [1].

\section{Introduction}

In the $19^{\text {th }}$ century, Tartu was in the same Czarist region as Riga, which had strong intellectual links with Tartu. Hundred and hundreds Latvian students studied in Tartu University, which offered ethnic Latvians the opportunity to receive an academic education and organise academic fraternities' [2].

Estonia's first song festival was held here in the $19^{\text {th }}$ century, as the country started to rediscover its national identity. By the late 1910s, Tartu University had become the centre of Estonia's national movement. In the 1920s and 30s, with $3,000-5,000$ students and the oldest university in the Baltics, Tartu was the intellectual hub of Estonia.

In the following article we want to give readers a short overview of the development of public health in Estonia: a review of the history of sanitary-topographical research organised by the department of public health of Tartu University in the all counties of Estonia in the 1920s and 30s.

\section{Public Health at the Birth of the Republic of Estonia}

By 1920, doctors knew how to control infectious diseases, if not how to treat them. In Tartu, Estonia, for example, vaccination had already almost eliminated smallpox; cholera had been virtually wiped out by public health measures; and typhoid fever and dysentery were in decline.

Nevertheless, infectious diseases were still the main killers: pneumonia, tuberculosis, gastro-intestinal infections and diphtheria accounted for more than a third of all deaths in Estonia [3].

In 1918 Estonia gained its independence which made it possible to lay the basis for a national university with the national staff who would start working on 
different matters concerning Estonia. At the same time it faced the serious task of setting up a national health care systems. The same can be said about public health research in the Department of Public Health of Tartu University [4].

In 1919, when the national university was opened, Estonian became the language of tuition and administration. With the birth of the independent republic the Department of Public Health of the Tartu University became Estonianspeaking. The staffing of the university was a complicated matter as most of the former professors had left Estonia. At the same time many well-known Estonian scientists returned to their native country and started work at the University [5].

\section{Ernst Fehrmann}

Until 1920 senior assistant, Doctor of Medicine, Ernst Fehrmann, who had to leave, however, because he could not speak Estonian, gave lectures in hygiene in Tartu University. He moved to Riga where he worked as a lecturer of hygiene [6]. Then in 1921 he was elected assistant professor of hygiene. Six years later in 1927 E. Fehrmann was elected full professor of hygiene. He worked as a holder of the Chair of Hygiene at the Latvian University from 1922 until his emigration to England in 1939 [7].

\section{Alexander Rammul}

E. Fehrmann's successor at Tartu University was a professor from Kasan University, Alexander Rammul, and also Doctor of Medicine, who was Estonian by nationality. He had graduated from Tartu University in 1899 after which he had worked as an assistant for Professor G. V. Hlopin at the Department of Public Health [8]. Later he had moved to Russia and obtained his doctor's degree at the University of Odessa in 1909. After that he had worked in Moscow as a health service doctor and from 1915 on as a professor at Kasan University. He left Kasan for Tartu in 1920 and was elected professor in ordinary at the Department of Public Health [9].

Alexander Rammul had wide knowledge in contemporary hygiene, as he had studied and improved his knowledge in major Russian and also western universities. His main research fields were communal, water and food hygiene, on which he published several studies in Estonian, Russian, German and French [10]. Dr. Rammul was Head of the Department of Public Health of Tartu University throughout the period of the first Republic of Estonia, that is up to 1940, when he retired [11].

Professor Rammul's retiring in 1940 was expected to bring along changes for the Department. There was hardly anyone, though, to forsee the extent of the virtual changes to come. In the same year the Soviet Union annexed the Republic of Estonia.

The period among 1920-1940 saw the accomplishment of three Doctor's thesis (Paul Põder, Mihkel Kask, Siim Lind), [12] four Master's thesis and fourteen prize thesis by students [13]. 


\title{
Saaremaa tervishoinline kirjeldus.
}

\section{Description sanitaire de l' arrondissement de Saare (0esel).}

\author{
Toimetaja - Rédacteur \\ p r 0 f. A. $\mathbf{R}$ a $\mathbf{m} \mathbf{m} \mathbf{u}$.
}

Tartus, 1928.

E. V. Tervishoiu- ja Hoolekandevalitsuse ja Tartu Ulikooli Tervishoiu Instituudi väljaanne.

Editton de I'Rdmintstration d'Hygiene et d'Assistance pub ique de la Rłpublique d'Estonie et de I'Institut d'Hygiene de rUniversite da Tartu (Dorpat).

The title page of the book

about the description of Saarema Island sanitary-topography 
Eesti vallad 1939 . .

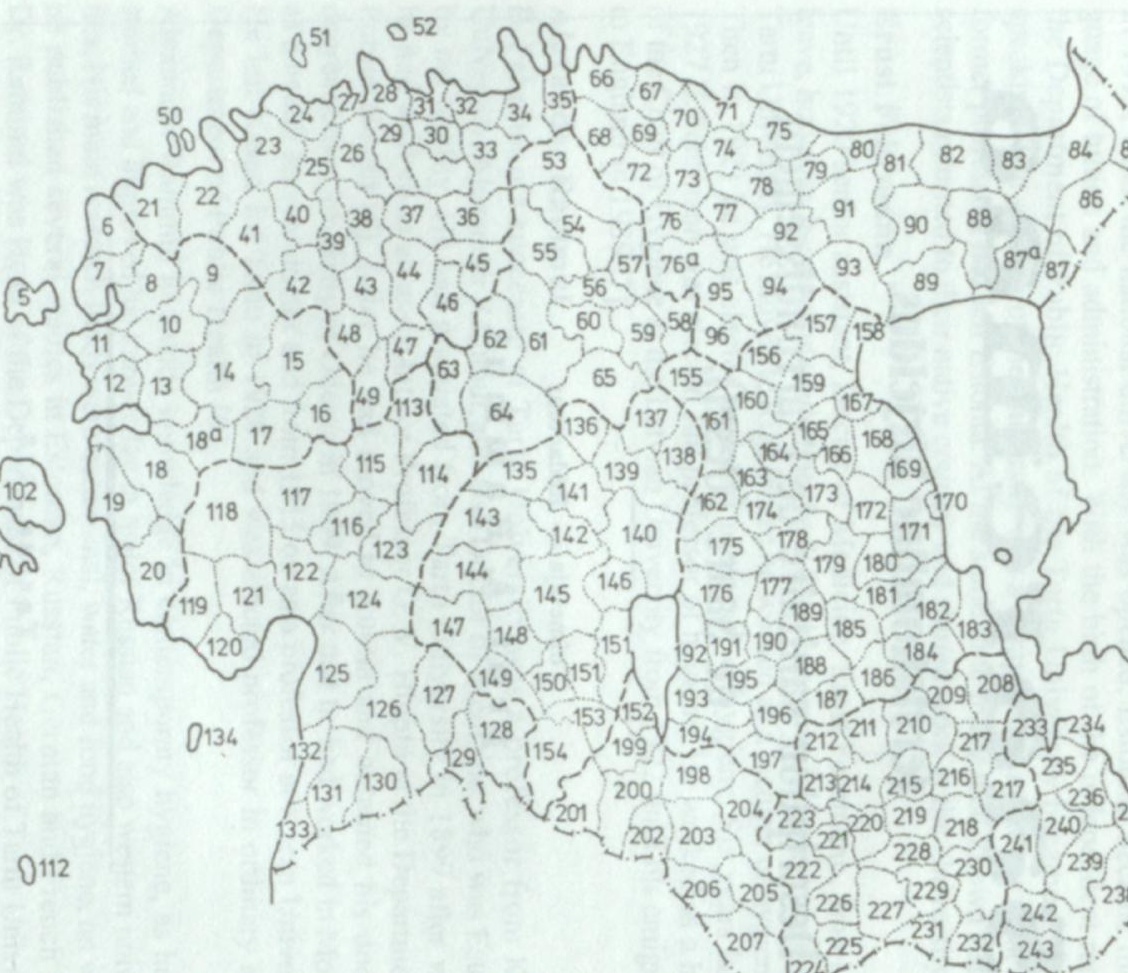




\section{Mihkel Kask}

One of the most outstanding students of professor Rammul was Mihkel Kask who, after defending his thesis, became senior assistant and lecturer at the Department. M. Kask carried on his teacher's research on communal, water and food hygiene [14].

In 1930s Mihkel Kask, who played an outstanding role in public health education in Estonia, began his teaching and research at the chair of hygiene [15]. His dream was a healthy individual, not a treated and recovered one. He worked his whole life to bring this dream into reality [16]. He graduated from the University of Tartu in 1929, worked at the chair of hygiene, participated in the above mentioned sanitary-topographical studies, more than once improved his knowledge abroad (received support from Rockefeller Foundation, USA) [17]. It was clear for him from the beginning that people themselves must take care of their health and he tried to teach it to his students as well as to the whole population [18]. In 1937 he began his regular presentations on the radio, which were called "Health minutes" and took place every week, being very popular among people [19].

The doctoral thesis of Mihkel Kask, defended in 1933, concentrates on the situation of public health in the Tartumaa district of Estonia [20]. The work possesses a special importance, since it remains as one of the fundamental sources of information about everyday life in the Estonian agrarian society. $\mathrm{M}$. Kask classified the general situation in public health as unsatisfactory [21].

\section{Sanitary-topographical (medico-geographical) studies}

The most extensive project undertaken by the Department then was concerned with sanitary-topographical (medico-geographical) studies that covered all the counties of Estonia. The State Health Department supported the project. Yet, due to the lack of financial resources the accomplished studies were published in a very compressed form. The first edition came out in 1928 and comprised material about Saaremaa Island [22] while the last one, about the Tartu district, was published ten years later, in 1938 [23]. All in all 11 collections on all the counties of Estonia were released.

Alexander Rammul launched and led a vast study on sanitary-topographical conditions in all 11 counties of Estonia [24]. It was an unprecedented initiative as no country has so far undertaken a study comprising all counties. Usually such studies had confined to single areas. The field works were preceded by thorough preparation of detailed question lists. Students of medicine, wouldbe doctors, mainly carried out the field works. The study was launched in 1922 and finished in 1930 [25]. The aim of these studies was to ascertain the conditions of living of people and public health aspects throughout Estonia. The attention was paid to housing, baths, nutrition, drinking water, everyday habits [lifestyle], social activities, health status, prevalence of chronic and mental diseases etc. The other aim was to study different counties in as short period as possible in order to make the results comparable [26]. 


\section{Finances}

The interest of the Republic of Estonia in such study is demonstrated by the fact that the State Health Department financed it. Yet, the financial situation of the republic at that time was far from good and the sums were annually cut. This is why the study had to be published in a rather compressed form [27]. All in all 11 collections [volumes] on all the counties of Estonia were released.

\section{Content of published collections}

The first three parts of the published collections concentrated on the geographical, geological and climatic conditions, what were to serve as a necessary background for the better understanding of health conditions? General objects of the inspection were the rural dwelling houses, baths or so-called saunas, toilets and wells. Additional attention was paid to health, eating habits, use of alcohol, clothes, shoes and bodily cleanliness. Also, folk medicine, the pregnancy period and taking care of infants were described [28].

The studies showed that the situation in hygiene in the Estonian countryside was much lower than in towns. According to the studies, traditional and very primitive huts without chimneys were not used for living any more. Yet, in most of the new farmhouses as well the conditions of ventilation, lighting and general hygiene were poor. For example, most of the counties lacked any conveniences of electric light; petroleum lamps were still used instead. On the other hand, saunas were very widely spread and popular among country folk. Saunas were used once a week on the average [29].

\section{Problems and solutions}

All the counties shared a problem that was becoming serious- the pollution of wells. Cattle-sheds and toilets often stood very close to them and favoured the pollution of drinking water. That is why efforts were made to carry out campaigns explaining the importance of artesian wells for the health of rural population. The situation was unsatisfactory although by the $20 \mathrm{~s}$ and $30 \mathrm{~s}$ two thirds of the rural people were provided with toilets [30].

Under such circumstances the building of artesian wells was forced on the peasantry by corresponding laws by both state and local authorities.

The aim and task of the sanitary-topographical study was to find out to what extent do the morbidity and mortality as well as general health condition depend on the way of life, customs, living condition and food and other factors. These descriptions give a very precious picture of the life in the Republic of Estonia in the 1920s [31]. Unfortunately, the results of the study could not be fully used in forming health policies for the future, as Estonia was annexed in 1940.

\section{Conclusion}

In conclusion we can say that the collections on description of sanitary conditions and health care published during the period under discussion and drawing public attention to the main problems helped to improve notably the sanitary conditions in the Republic of Estonia. Rural population with poor 
knowledge in elementary hygiene in the 1920s had become conscious of the importance of hygiene by the end of the 1930s. Estonia had developed into a country with modern standards in public health. For a contemporary reader these publications represent a valuable historical source in the first place. They can be reached and used by researchers on the social history of Estonia as well as by explorers of local history. A thorough description of public health conditions in the Estonian counties between the two world wars gives a colourful picture of everyday life of Estonians during their first republic.

\section{References}

1. Berridge V., Harrison M., Weindling $P$. The impact of war and depression, 1918 to 1948 // Caring for Health: history and diversity / Webster, Charles. [Edit.]. - Buckingham: Open University Press, 1997, p. 87-106.

2. Rasmanis E. Reiters L. Latvian Academic fraternities and Medicine. The Case of Fraternitas Metropolitana // Acta Medico-Historica Rigensia: Volumen Il [XXI]. - Riga: Pauli Stradini Museum Historia Medicinae, 1994, p. 185-192.

3. Kask M. Sugemeid Tartumaa tervishoiulistest oludest. Väitekiri arstiteaduse doktori astme saamiseks. - Tartu, 1933.

4. Saava A., Sepp A., Uibo M. 100 aastat iseseisvat hügieeniõppetooli Tartu Ülikoolis // Eesti Arst. - Tallinn, 1995, lk. 100-104.

5. Käbin I. Die medizinische Forschung und Lehre an der Universitåt Dorpat / Tartu 1802-1940 // Sydsvenska medicinhistoriska sällskapets årsskrift. Supplementum nr. 6, 1986.

6. Brennsohn I. Die Aerzte Estlands vom Beginn der historischen Zeit bis zur Gegenwart. - Riga, 1922, S. 437.

7. Lenz W. Deutschbaltisches biographisches Lexikon: 1710-1960. - Köln, 1970, P. 209.

8. Brennsohn I. Die Aerzte Estlands vom Beginn der historischen Zeit bis zur Gegenwart. - Riga, 1922, S.500.

9. Eesti Biograafilie Leksikon // Akadeemilise Ajaloo Seltsi toimetised. - Tartu, 1926-1929, Ik. 411.

10. Eesti Biograafilise Leksikoni Täiendusköide. - Tartu, 1940, lk. 265-266.

11. Kalnin V. 75 let so vremeni osnovanija kafedri gigieni Tartuskogo universiteta. Tartuskii gosudarstvennij universitet // Materiali nauchnoi konferentsii. - Tartu, 1970, Ik. 15-36.

12. Kask M., Normann H. Tartu Ülikooli tervishoiu instituudist ja selle tegevusest 1895. - 1935.a. // Eesti Arst, XIV, nr. 4. - Tartu, 1935, Ik. 275-306.

13. Siilivask K., Palamets H. Tartu Ülikooli ajalugu III. 1918-1982. - Tallinn, 1982, $149-150 ; 159-161 ; 174 ; 261$.

14. Album Academicum Universitatis Tartuensis 1918-1944, II. Compiled by Lindström, Lauri. \& Hiio, Toomas. - Tartu, 1994, p. 4807.

15. Tartu Riikliku Ülikooli õppe-teaduskoosseisu biobibliograafianimestik 1944-1980. - Tallinn, 1987, 77-78. 
16. Saava A., Maaroos H.-I. [eds.]. Public Health and Family Medicine. Proceedings of WHO/World Bank Seminar. - Tartu 1994. Education and Research in Public Health and Family Medicine. Seminar 28-29. November 1994. Estonia.

17. Tervishoiu Instituut. TI kirjavahetus ja tegevusaruanded 1936-1940.

18. Otter K. 90 aastat hügieeniprofessor Mihkel Kask sünnist // Tartu Ülikooli ajaloo küsimusi, nr. 28. - 1993, lk. 3-8.

19. Sepp A. The Department of Public Health of the University of Tartu during 1920-1940 // Public Health - Past and Present. Abstracts of Conference dedicated to the 100-year anniversary of the Department of Public Health. 20-21 April 1995. - Tartu, 1995. Pp. 75-76.

20. KaskM. Sugemeid Tartumaa tervishoiulistest oludest. Väitekiri arstiteaduse doktori astme saamiseks. - Tartu, 1933.

21. Sepp A., Sepp H. Tartumaa tervishoiulistest oludest 1930.a. alguses (Dr. Mihkel Kase văitekirja järgi) // Tartu Ülikooli ajaloo küsimusi, nr.29. - 1997, lk. 179-186.

22. Rammul A. Saaremaa tervishoiuline kirjeldus. - Tartu, 1928.

23. Rammul A., Kask M. Tartumaa tervishoiuline kirjeldus. - Tartu, 1938.

24. Normann H. Eesti meditsiiniline bibliograafia 1918-1930 ühes piirialadega. Tartu, 1932, Ik. 98-99.

25. Sepp A. Sanitary-topographical studies in Estonia during 1920s and 30s // Theses Historiae Scientiarium Baltica II. - Riga, 1996. Pp. 96-97.

26. Normann H. Eesti meditsiiniline bibliograafia 1931-1932 ühes piirialadega. Tartu, 1933, Ik. 33.

27. Sepp A., Sepp H. Tartumaa tervishoiulistest oludest 1930.a. alguses (Dr. Mihkel Kase väitekirja järgi) // Tartu Ülikooli ajaloo küsimusi, nr. 29. - 1997, Ik. 179-186.

28. Normann H. Eesti meditsiiniline bibliograafia 1933-1934 ühes piirialadega. Tartu, 1935, lk. 53-54.

29. Sepp A., Sepp H. Tartumaa tervishoiulistest oludest 1930.a. alguses (Dr. Mihkel Kase văitekirja järgi) // Tartu Ülikooli ajaloo küsimusi, nr. 29. - 1997, lk. 179-186.

30. Sepp A., Sepp H. Tartumaa tervishoiulistest oludest 1930.a. alguses (Dr. Mihkel Kase väitekirja järgi) // Tartu Ülikooli ajaloo küsimusi, nr. 29. - 1997, Ik. 179 -186.

31. Rammul A. Läănemaa tervishoiuline kirjeldus. - Tartus, 1929; Rammul A. Pärnumaa tervishoiuline kirjeldus. - Tartus, 1930; Rammul A. Virumaa tervishoiuline kirjeldus. - Tartus, 1931; Rammul A. Vorumaa tervishoiuline kirjeldus. - Tartus, 1932; Rammul A. Valgamaa tervishoiuline kirjeldus. Tartus, 1933; Rammul A. Viljandimaa tervishoiuline kirjeldus. - Tartus, 1933; Rammul A. Järvamaa tervishoiuline kirjeldus. - Tartus, 1934; Rammul A. Petserimaa tervishoiuline kirjeldus. - Tartus, 1935; Rammul A. Harjumaa tervishoiuline kirjeldus. - Tartus, 1937

Alar Sepp, $M D$, lecturer

Helena Sepp, $M A$, researcher

University of Tartu, Department of Public Health, Ravila 19, 50411, Tartu, Estonia E-mail: asepp@ut.ee 